
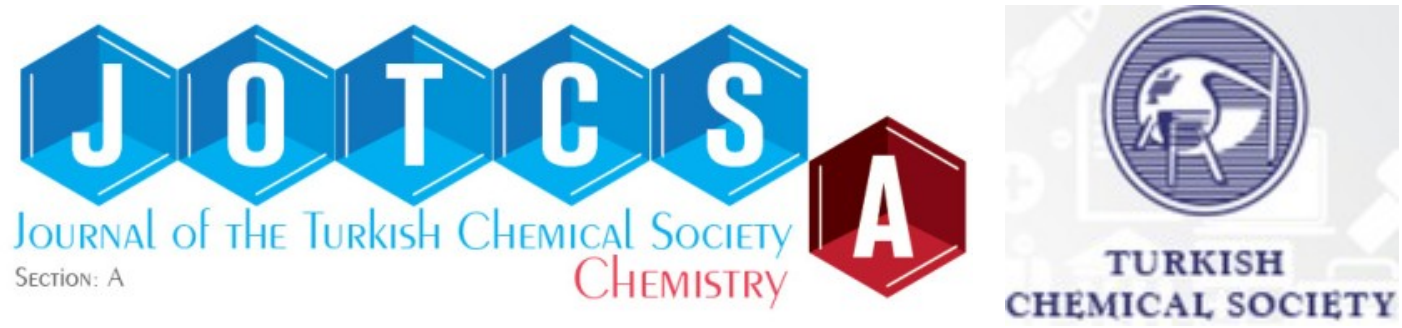

\title{
STABILITY INDICATING ANALYTICAL METHOD DEVELOPMENT AND VALIDATION OF ELTROMBOPAG OLAMINE IN TABLET DOSAGE FORM BY RP-UPLC
}

\author{
Dr. Ajay I. Patel ${ }^{1} \Delta$ D, Shweta Gosai*1 $\triangle$ iD, Kajal Jadav ${ }^{1}$ iD, Dr. Amit J. Vyas ${ }^{1} \Delta$ iD, \\ Dr. Ashok B. Patel ${ }^{1}$ iD, Dr. Nilesh K. Patel ${ }^{1} \square$ iD
}

1- B. K. Mody Government Pharmacy College, Rajkot-360003, Gujarat, India.

\begin{abstract}
A simple, precise, and accurate stability indicating isocratic Reverse Phase Ultra-Performance Liquid Chromatographic (RP-UPLC) method was developed for quantitative determination of Eltrombopag olamine in the presence of degradant products. The method was developed using Acquity UPLC BEH C 18 $(50 \times 2.1 \mathrm{~mm}, 1.7 \mu \mathrm{m})$ column with mobile phase containing water (adjusted to $\mathrm{pH} 3$ with formic acid) and acetonitrile in the ratio of 30:70. The eluted compound was monitored at $244 \mathrm{~nm}$ and run time was within 2 min. Eltrombopag olamine was subjected to the stress condition of oxidative, acid, base, thermal, and photolytic degradation. The drug was found to degrade significantly in acid, base, and oxidative stress condition and stable in thermal and photolytic degradation conditions. The degradation products were well resolved from the main peak, providing stability indicating power of the method. The developed method was validated as per ICH Q2(R1) guideline with linearity range was between $25-75 \mu \mathrm{g} / \mathrm{mL}$, \% recovery range was found as 99.8-101.9 and precision was found as RSD less than 2.
\end{abstract}

Keywords: Eltrombopag olamine, ultra performance liquid chromatography, stability indicating, force degradation, validation.

Submitted: April 21, 2020. Accepted: . September 30, 2020.

Cite this: Patel A, Gosai S, Jadav K, Vyas A, Patel A, Patel N. STABILITY INDICATING ANALYTICAL METHOD DEVELOPMENT AND VALIDATION OF ELTROMBOPAG OLAMINE IN TABLET DOSAGE FORM BY RP-UPLC. JOTCSA. $2020 ; 7(3): 845-50$.

DOI: https://doi.org/10.18596/jotcsa.724484.

*Corresponding author. E-mail: shwetagosai97@gmail.com.

\section{INTRODUCTION}

Eltrombopag is formulated as Eltrombopag olamine salt with the chemical name of $3-\{(2 Z)-2-[1-(3$, 4-dimethylphenyl) -3-methyl-5-oxo-1, 5-dihydro4H-pyrazol-4-ylidene] hydrazine\}-2-hydroxy-3biphenylcarboxylic acid-2-aminoethanol (1:2) (1). Eltrombopag olamine is a thrombopoeitin receptor agonist used in idiopathic thrombocytopenic purpura
(2). Eltrombopag olamine is a member of biphenylhydrazone class which stimulates activation of the cytoplasmic tyrosine kinases Janus kinase (JAK) 2 and tyrosine kinase 2 and signal transducers and activators of transcription five (STAT) 5 by activating thrombopoeitin receptor, resulting in megakaryocyte proliferation and differentiation into platelets. The structure of Eltrombopag olamine is given in Figure 1. 
<smiles>CC1=NN(c2ccc(C)c(C)c2)C(=O)/C1=N\Nc1cccc(-c2cccc(C(=O)O)c2)c1O</smiles>

Figure 1. Structure of Eltrombopag olamine.

Forced degradation is degradation of drug substance and drug product at conditions more harsh than accelerated conditions. It is required to exhibit specificity of stability indicating methods to solve stability related problems and it also provides an insight into degradation pathways and degradation products which helps in elucidation of the structure of degradation products. The drug is exposed to various stress conditions, which are acidic, basic, oxidative, thermal, and photolytic degradation with degradation between 5-20\% acceptance range (3$5)$.

Literature review revealed that there is no any pharmacopeial method available and various methods available are HPLC (6-7), HPLC stability (810), UV method (11), RP-UPLCMS (12) and LC-MS MS (13), but there is no single method available for stability indicating method for the estimation of Eltrombopag olamine by RP-UPLC. Ultraperformance liquid chromatography (UPLC) provides significant increase in resolution, sensitivity, and speed of analysis. As compared to HPLC, RP-UPLC takes less run time and less solvent consumption, so it lowers the cost and makes the technology ecofriendly. Thus, it is worthwhile to develop stability indicating analytical method for estimation of Eltrombopag olamine tablet dosage form by RPUPLC, which can be employed for routine analysis.

\section{MATERIAL AND METHOD}

\section{Chemicals and Reagents}

Eltrombopag olamine was kindly provided as a gift sample from Piramal Discovery Solution, Ahemdabad. Promacta tablet $(75 \mathrm{mg})$ was purchased from the market. HPLC grade acetonitrile, Milli Q water, AR grade formic acid, AR grade hydrochloric acid, AR grade sodium hydroxide, and hydrogen peroxide were used.

\section{Chromatographic Condition}

UPLC (Acquity UPLC, Waters) used, data were processed using Empower software. Chromatographic separation was performed using UPLC BEH C $18(50 \mathrm{~mm} \times 2.1 \mathrm{~mm}, 1.7 \mu \mathrm{m})$ column. The mobile phase consists of water $\mathrm{pH} 3$ with formic acid and acetonitrile in ratio of $30: 70$. The flow rate was set to be $0.5 \mathrm{~mL} / \mathrm{min}$. The injection volume was
$3 \mu \mathrm{L}$. The detection was carried out at $244 \mathrm{~nm}$ at column temperature $30^{\circ} \mathrm{C}$ within run time of $2 \mathrm{~min}$.

\section{PREPARATION OF THE STANDARD SOLUTION}

A standard solution of Eltrombopag olamine $(50 \mu \mathrm{g} /$ $\mathrm{mL}$ ) was prepared by dissolving an $25.6 \mathrm{mg}$ (equivalent to $20 \mathrm{mg}$ of Eltrombopag) of Eltrombopag olamine in acetonitrile : water 70:30 (v/v) (diluent).

\section{Preparation of Stock Solution}

A standard stock solution of $200 \mu \mathrm{g} / \mathrm{mL}$ for Eltrombopag olamine was prepared by using acetonitrile : water 70:30 (v/v) as a diluent.

\section{Preparation of Sample Solution}

20 tablets of Promacta (75 mg of Eltrombopag) were weighed and finely powdered. About $97 \mathrm{mg}$ (equivalent to $20 \mathrm{mg}$ of Eltrombopag) of tablet powder was weighed and diluted to obtain $50 \mu \mathrm{g} / \mathrm{mL}$ solution of Eltrombopag olamine.

\section{FORCED DEGRADATION STUDIES}

The study was carried out to specify the method by ensuring the separation of degradant's peaks and standard drug peak. Acidic degradation was carried out using $1 \mathrm{~N} \mathrm{HCl}$ at $60{ }^{\circ} \mathrm{C}$ for $2.5 \mathrm{~h}$ and alkaline degradation was performed with $0.05 \mathrm{~N} \mathrm{NaOH}$ at room temperature for $24 \mathrm{~h}$ and then the mixture was neutralized, diluted, and filtered. Oxidation studies were conducted using $0.3 \% \mathrm{H}_{2} \mathrm{O}_{2}$ for $1 \mathrm{~h}$. Thermal degradation was carried out $60^{\circ} \mathrm{C}$ for $1 \mathrm{~h}$. For photolytic degradation, the powdered drug was exposed to UV light for $1 \mathrm{ICH}$ cycle.

\section{Preparation of force degradation solution}

About $97 \mathrm{mg}$ of tablet powder was used to perform force degradation, which was, after neutralization, diluted to obtain $50 \mu \mathrm{g} / \mathrm{mL}$ solution of Eltrombopag.

\section{METHOD VALIDATION (14)}

Analytical validation parameters for this proposed method were determined according to ICH (Q2R1) guideline. 


\section{Linearity}

The stock solution of $200 \mu \mathrm{g} / \mathrm{mL}$ was diluted appropriately to obtain a concentration range of 50 $150 \%$ i.e; $25-75 \mu \mathrm{g} / \mathrm{mL}$ of working sample i.e; 50 $\mu \mathrm{g} / \mathrm{mL}$ of Eltrombopag olamine.

a) $50 \%: 2.5 \mathrm{~mL}$ of stock solution was diluted up to $20 \mathrm{~mL}$ to obtain $25 \mu \mathrm{g} / \mathrm{mL}$.

b) $75 \%$ : $3.5 \mathrm{~mL}$ of stock solution was diluted up to $20 \mathrm{~mL}$ to obtain $35 \mu \mathrm{g} / \mathrm{mL}$.

c) $100 \%$ : $5 \mathrm{~mL}$ of stock solution was diluted up to $20 \mathrm{~mL}$ to obtain $50 \mu \mathrm{g} / \mathrm{mL}$.

d) $120 \%$ : $6 \mathrm{~mL}$ of stock solution was diluted up to $20 \mathrm{~mL}$ to obtain $60 \mu \mathrm{g} / \mathrm{mL}$.

e) $150 \%: 7.5 \mathrm{~mL}$ of stock solution was diluted up to $20 \mathrm{~mL}$ to obtain $75 \mu \mathrm{g} / \mathrm{mL}$.

\section{LOD and LOQ}

The limit of detection (LOD) and limit of quantification (LOQ) were calculated by Calibration curve method.

$\mathrm{LOD}=3.3 \times \mathrm{SD} /$ slope

$\mathrm{LOQ}=10 \times \mathrm{SD} /$ slope

\section{Specificity}

Specificity was performed by injecting diluent, placebo and sample solution to check the interference of excipients.

\section{Precision}

Repeatability was performed under 6 replicates of Eltrombopag olamine $(50 \mu \mathrm{g} / \mathrm{mL})$. Intra-day and inter-day variations of Eltrombopag olamine was performed in triplicate at three different concentration levels 50, 100, 150\% (25, 50 and 75 $\mu \mathrm{g} / \mathrm{mL})$.

\section{Accuracy}

The accuracy was carried out by spiking in triplicate of three different concentrations 50,100 and $150 \%$ $(25,50$ and $75 \mu \mathrm{g} / \mathrm{mL}$ of Eltrombopag olamine) of target concentration of drug to placebo and \% recovery was calculated.

\section{Robustness}

The robustness of method was established by applying small deliberate changes in the experimental condition. The changes made in flow rate $\pm 0.05(0.45 \mathrm{~mL} / \mathrm{min}, 0.5 \mathrm{~mL} / \mathrm{min}, 0.55$ $\mathrm{mL} / \mathrm{min})$, Temperature $\pm 2^{\circ} \mathrm{C}\left(28^{\circ} \mathrm{C}, 30^{\circ} \mathrm{C}, 32^{\circ} \mathrm{C}\right)$ and $\mathrm{pH} \pm 0.2(2.8,3,3.2)$.

\section{Assay of Tablet Dosage Form}

Twenty tablets were weighed and powdered. The mass equivalent of $97 \mathrm{mg}$ of sample (equivalent to $20 \mathrm{mg}$ of Eltrombopag olamine) was taken into a 50 $\mathrm{mL}$ volumetric flask. The solution is further diluted to obtain concentration of $50 \mu \mathrm{g} / \mathrm{mL}$.

\section{RESULT AND DISCUSSION}

\section{Optimized Condition}

Initially methanol, acetonitrile, and water were tried in different concentrations for mobile phase selection. The optimized mobile phase was water $\mathrm{pH}$ 3 with formic acid and acetonitrile (30:70\% v/v). Chromatographic separation was performed using UPLC BEH C $18(50 \mathrm{~mm} \times 2.1 \mathrm{~mm}) \times 1.7 \mu \mathrm{m}$. The flow rate was set to be $0.5 \mathrm{~mL} / \mathrm{min}$. The injection volume was $3 \mu \mathrm{L}$ with detection wavelength 244 $\mathrm{nm}$. The optimized chromatogram is given in Figure 2.

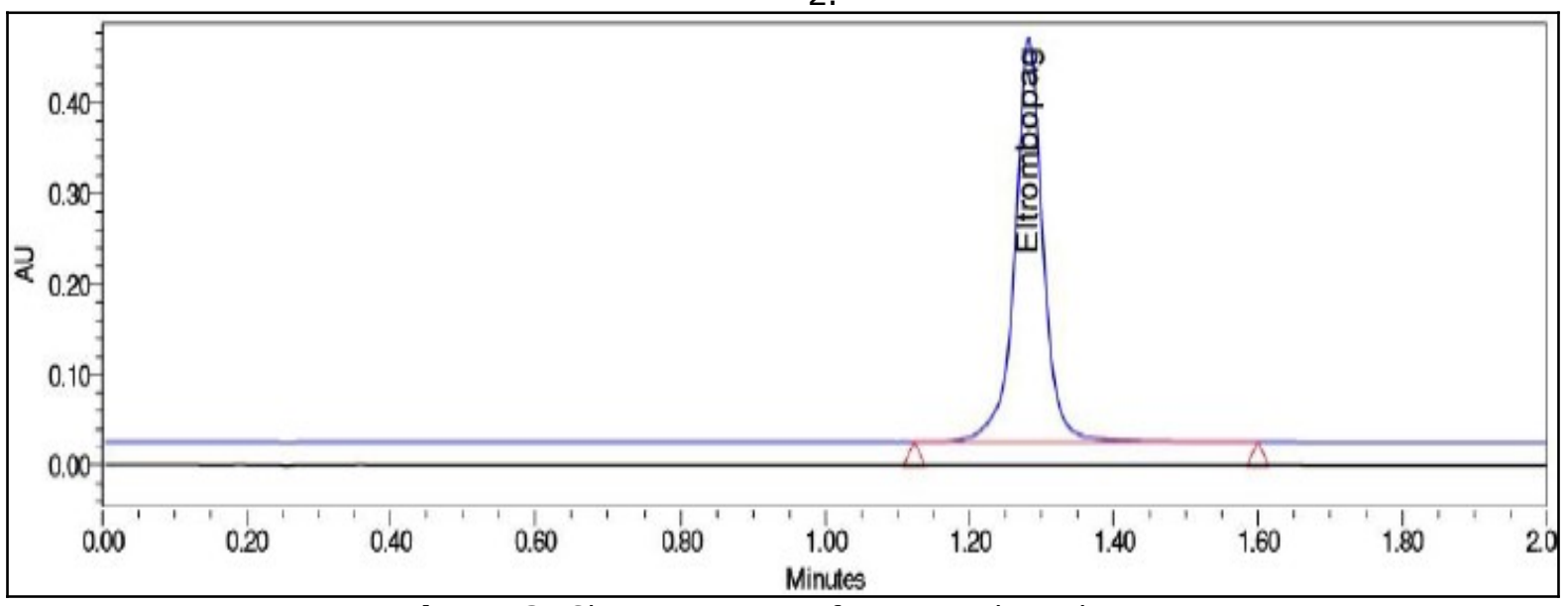

Figure 2. Chromatogram of optimized condition.

\section{System Suitability Parameter}

The system suitability parameter is shown in Table 1, which shows that all the parameters are within the acceptance limit i,e; Theoretical plates is greater than 2000 and tailing factor is less than 2.

Table 1. Summary of System Suitability Parameters

\begin{tabular}{|c|c|c|c|c|}
\hline Drug & Retention Time & Area & Theoretical Plates & Tailing Factor \\
\hline $\begin{array}{c}\text { Eltrombopag } \\
\text { olamine }\end{array}$ & 1.30 & 1252210 & 6848 & 1 \\
\hline
\end{tabular}




\section{Forced degradation study}

Force degradation study shows \% degradation was obtained between $5-20 \%$ in acidic, basic, and oxidative stress condition and drug was stable in thermal and photolytic degradation. The degradation order was acidic $>$ oxidative $>$ basic $>$ photolytic and thermal. Peak purity test passes as there was no any unknown peak get merged in API peak, which is also confirmed from purity angle is less than purity threshold. Force degradation data is given in Table 1 and chromatograms of different stress condition is given in Figure 3 .

Table 2. Forced degradation summary.

\begin{tabular}{|c|c|c|c|}
\hline Degradation Condition & Purity Threshold & Purity Angle & \% Degradation \\
\hline Acidic degradation & 0.268 & 0.071 & 6 \\
\hline Basic degradation & 0.314 & 0.149 & 4.8 \\
\hline Oxidative degradation & 0.262 & 0.049 & 5.4 \\
\hline Photolytic degradation & 0.262 & 0.049 & 0.2 \\
\hline Thermal degradation & 0.271 & 0.080 & 0.3 \\
\hline
\end{tabular}

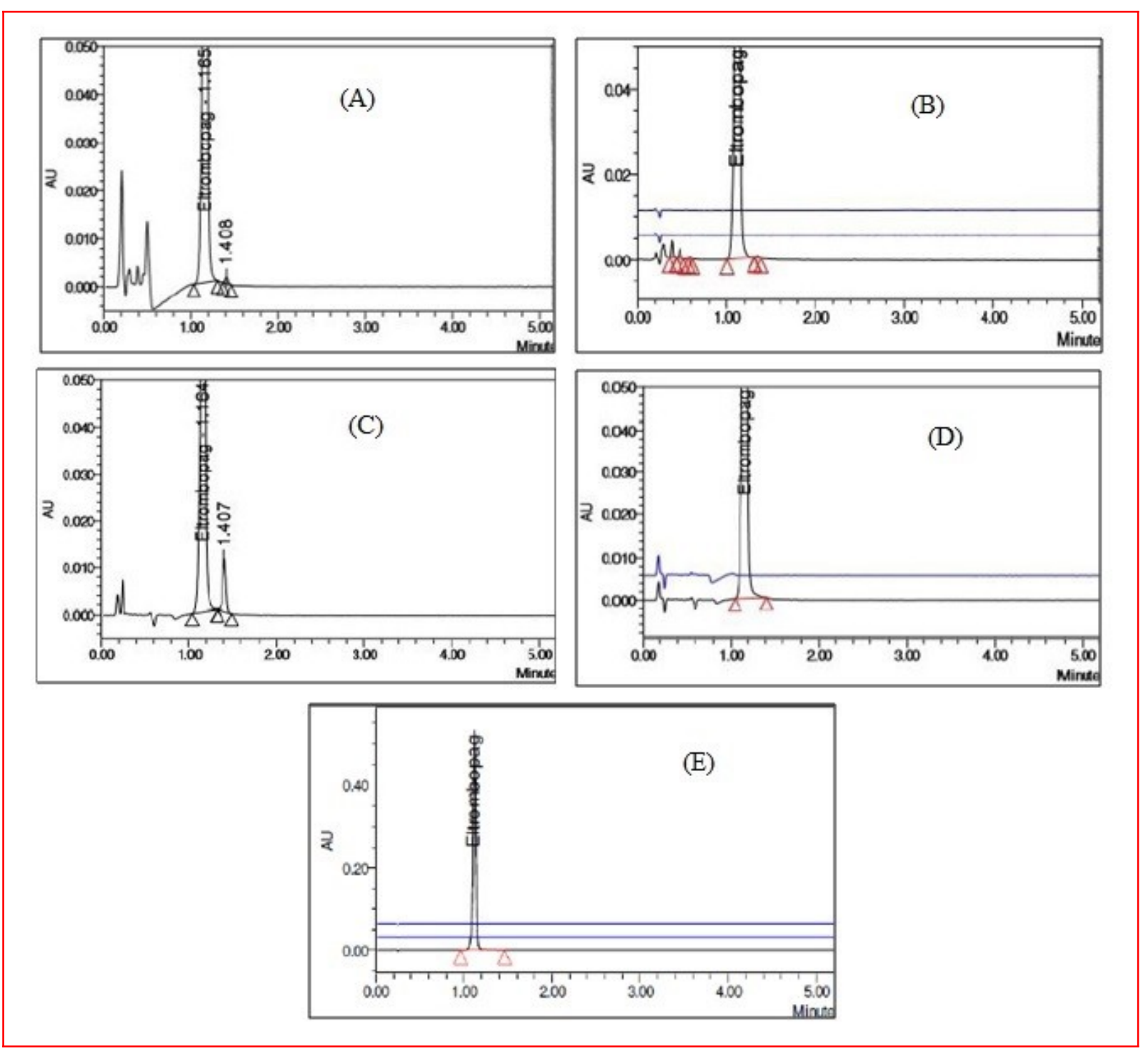

Figure 3. Force degradation chromatograms of A) Acidic condition B) Basic condition (Overlay of placebo, blank and sample) C) Oxidative condition D) Thermal condition (Overlay of placebo and sample) E) Photolytic condition (Overlay of placebo and sample).

\section{METHOD VALIDATION}

Linearity: The calibration curve obtained for Eltrombopag olamine in the range of $25-75 \mu \mathrm{g} / \mathrm{mL}$ and the correlation coefficient was found to be 0.999. Linearity spectra and graph is given in Figures 4 and 5. 


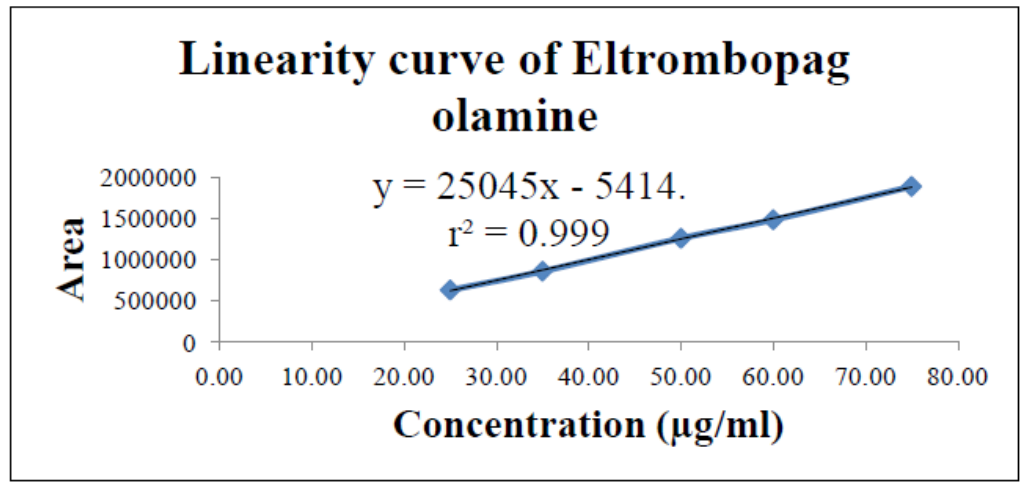

Figure 4. Linearity curve of Eltrombopag olamine.

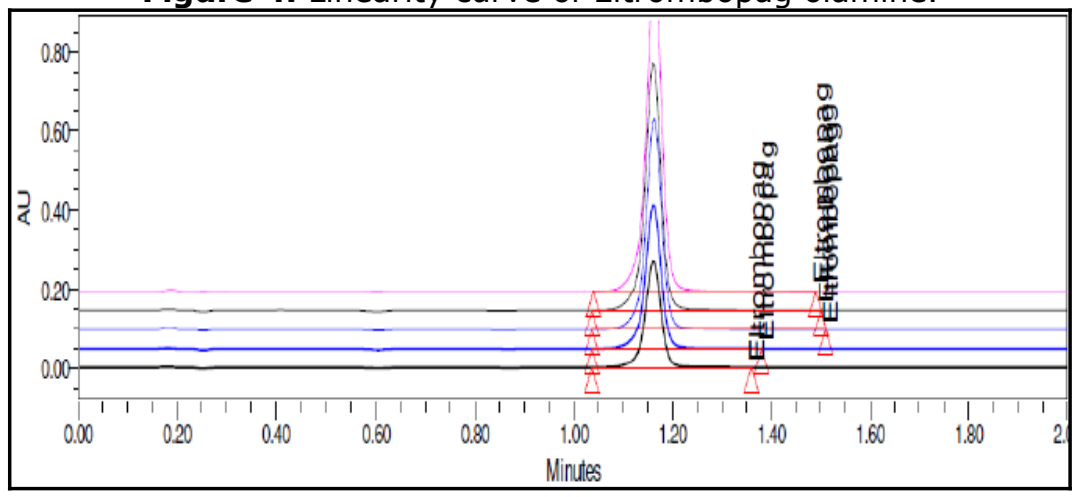

Figure 5. Linearity overlay chromatogram of Eltrombopag olamine.

LOD and LOQ: LOD and LOQ were found to be 1.19 $\mu \mathrm{g} / \mathrm{mL}$ and $3.59 \mu \mathrm{g} / \mathrm{mL}$.

Specificity: Specificity study shows that there no any interference of the diluents and placebo at the retention time of drug peak. Also purity angle is obtained less than purity threshold, so peak purity shows a positive result. Also \% interference was found as $0.02 \%$, thus the method is specific.

Precision: Repeatability and intraday, interday precision for RP-UPLC method was measured in terms of RSD and RSD was found to be less than 2.Thus, the method is precise. Results are shown in Table 2.

Table 3. Summary of intraday and interday precision and accuracy.

\begin{tabular}{|c|c|c|c|c|c|}
\hline \multicolumn{3}{|c|}{ Precision } & $\begin{array}{c}\text { Interday } \\
\text { Precision }\end{array}$ & $\begin{array}{c}\text { Intraday } \\
\text { Precision }\end{array}$ & Accuracy \\
\hline \multirow{2}{*}{ Drug Name } & $\begin{array}{c}\text { Level (\%) } \\
(\mathbf{n}=\mathbf{3})\end{array}$ & $\begin{array}{c}\text { Conc. } \mathbf{( \mu g / m L )} \\
(\mathbf{n}=\mathbf{3})\end{array}$ & $\begin{array}{c}\text { \%RSD } \\
(\mathbf{n}=\mathbf{3})\end{array}$ & $\begin{array}{c}\text { \%RSD } \\
(\mathbf{n}=\mathbf{3})\end{array}$ & $\begin{array}{c}\text { \%Recovery } \\
\text { Range }\end{array}$ \\
\hline \multirow{2}{*}{$\begin{array}{c}\text { Eltrombopag } \\
\text { olamine }\end{array}$} & 50 & 25 & 0.43 & 0.18 & \multirow{2}{*}{$99.8-101.9$} \\
\cline { 2 - 5 } & 100 & 50 & 0.09 & 0.06 & \\
\cline { 2 - 5 } & 150 & 75 & 0.03 & 0.05 & \\
\hline
\end{tabular}

Accuracy:\% recovery was found between $98-102 \%$ specify that method developed is accurate. Result for accuracy is tabulated in Table 2 .

Robustness: Making deliberate changes in flow rate, temperature and $\mathrm{pH}$, the RSD of peak area was found to be less than 2, specifying that the method is robust and results remained unaffected by small variations of these parameters.

\section{Assay of tablet dosage form}

$\%$ Drug content of tablet dosage form of Eltrombopag olamine was found between $99-100 \%$. The data is given in Table 3 . Thus, the method can be used for routine assay of tablet dosage form. 
Table 4. Assay of Eltrombopag olamine.

\begin{tabular}{|c|c|c|c|}
\hline Drug & $\begin{array}{c}\text { CONC } \\
(\boldsymbol{\mu g / m L}) \\
(\mathbf{n = 3})\end{array}$ & CONC Mean \pm SD & $\begin{array}{c}\text { \% Assay } \\
(\mathbf{n = 3})\end{array}$ \\
\hline Eltrombopag olamine & 50 & $50.98 \pm 0.717$ & 101.96 \\
\hline
\end{tabular}

\section{CONCLUSION}

The developed stability indicating method for estimation of Eltrombopag olamine is simple and rapid. Data obtained from precision shows result in terms of RSD less than 2, which conclude that the method is reproducible and precise. Accuracy range is between $99.8-101.9 \%$ recovery ensure good accuracy and specificity shows no interference of diluent and placebo, indicating that the method is specific with good response for the estimation of Eltrombopag olamine. Deliberately changing the chromatographic conditions gives RSD less than 2 show developed method is robust in nature. Stress degradation carried out in acidic, basic, oxidative, thermal, and photolytic condition shows method was capable of quantifying drug in presence of degradants as peak purity of drug peak passes. Drug get degrade in acidic, basic, and oxidative condition indicate that drug is susceptible to these conditions and stable in thermal and photolytic degradation. From this, it is concluded that method is reliable for analysis of Eltrombopag olamine in tablet dosage form with its degradants.

\section{ACKNOWLEDGMENTS}

The authors gratefully acknowledge Piramal pharma solutions for providing all facilities to complete this research work.

\section{REFERENCES}

1. Zhang $Z$ and Kolesar JM. Eltrombopag: An Thrombopoietin Receptor Agonist for the Treatment of idiopathic Thrombocytopenic Purpura. Clinical Therapeutics. 2011; 33: 1560-76.

2. Gonzalez JR and Bastida JM. Eltrombopag in immune thrombocytopenia: efficacy review and update on drug safety. Therapeutic Advance in Drug Safety. 2018; 9: 263-85.

3. ICH - Harmonized Tripartite Guideline. Stability testing of New drug substance and products Q1A (R2). International Conference on Harmonization. IFPMA, Geneva, Switzerland, 2003.

4. Singh S and Bakshi M. Guidance on Conduct of Stress Tests to Determine Inherent Stability of Drugs. Pharmaceutical Technology. 2000; 1-14.

5. Blessy M, Patel RD, Prajapati PN and Agrawal YK. Development of forced degradation and stability indicating studies of drugs - A review. J. Phar. Anal. 2013; 4: 159- 65 .

6. Pal N, Pravalika P, Bhavani DS, Geetha R, Afreen $A$ and Rao AS. New method development and validation for the determination of Eltrombopag in bulk and tablet dosage form by HPLC. World journal of Pharmacy and Pharmaceutical science. 2018; 7: 1176-84.

7. Madasu RK, Isreal S and Rao NV. Development and validation for detection of DIC and IHC in Eltrombopag olamine tablet by RP-HPLC method. World journal of Pharmacy and Pharmaceutical science. 2018; 7: 744-62.

8. Sindhuriya M, Chaudhari GV, Shah $P$ and Khoja SS. Development and validation of Stability indicating RP-HPLC method for estimation of Eltrombopag olamine in pharmaceutical dosage form. European journal of Biomedical and Pharmaceutical science. 2018; 5: 454-60.

9. Manoharan G. Development and validation of Stability indicating RP-HPLC method for estimation of the Eltrombopag in bulk and tablet formulation. Asian journal of Chemical science. 2018 ; 4(1): 1-9.

10. Mohan TSSJ, Khagga $M$ and Jogia HA. Stability indicating UHPLC method development and validation for estimation of Eltrombopag and related impurities in tablet dosage form. Oriental journal of chemistry. 2018; 34: 1098-104.

11. Marakatham S, Vallikumari RV and Meruva SK. Spectrophotometric method for determination of Eltrombopag in bulk and pharmaceutical formulation. International journal of Research in Pharmacy and Biosciences. 2017; 4: 13-6.

12. Basha DM, Reddy GV, Rani TS, Susithra E and Chekkara R. RP-UPLC-MS assay method for Eltrombopag: application in pharmaceuticals, human plasma and urine samples. Asian J. Chem. 2015; 27: 4615-9.

13. Maddela R, Gajula R, Pilli NR, Siddiraju S, Maddela $S$ and Makula A. Liquid chromatographytandem mass spectrometric assay for Eltrombopag in $50 \mu \mathrm{l}$ of human plasma: A pharmacokinetic study. J. Pharm. Biomed. Anal. 2014; 1-23.

14. $\mathrm{ICH}$ - Harmonized Tripartite Guideline. Validation of analytical procedures: text and methodology Q2 (R1). International Conference on Harmonization. IFPMA, Geneva, Switzerland, 2005. 